\title{
Bacterial and Antimicrobial Susceptibility Profile and \\ Prevalence of Sepsis Among Burn Patients at the Burn Unit of Cipto Mangunkusumo Hospital
}

\section{RSCM Radhianie Djan, Zainul Halim}

\section{Introduction}

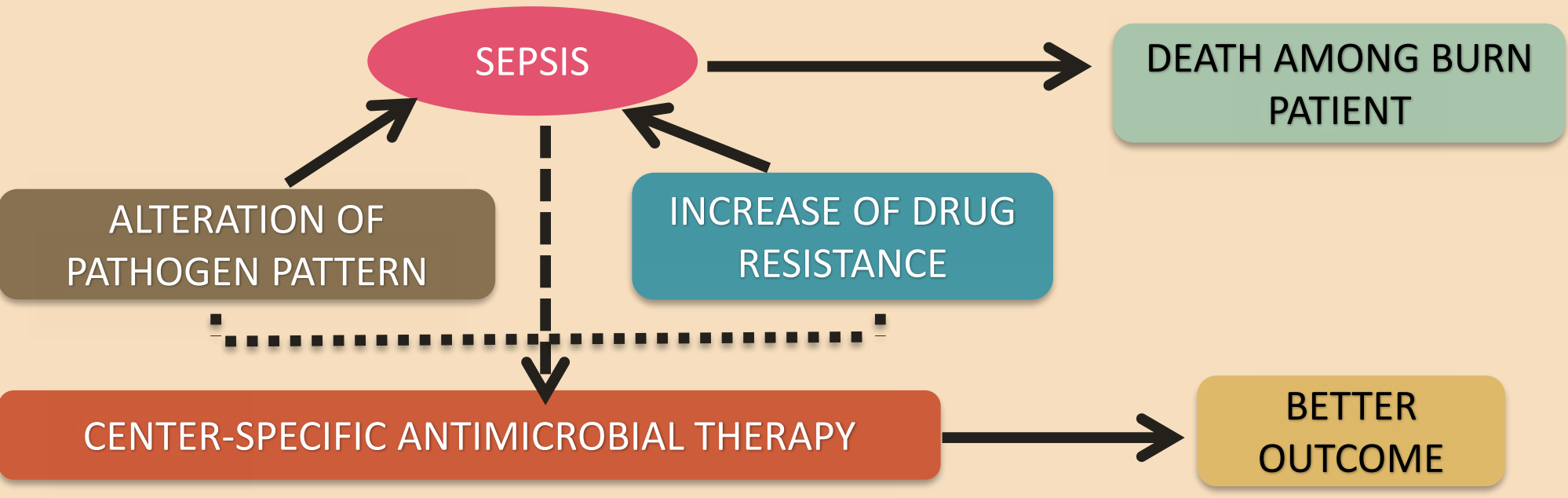

\section{Method}

- A Retrospective Study

- Conducted at Cipto Mangunkusumo Hospital Burn Unit

- September - November 2016

\section{Results}

Figure 1. Bacterial Isolates Pattern in the RSCM Burn Unit September - November 2016
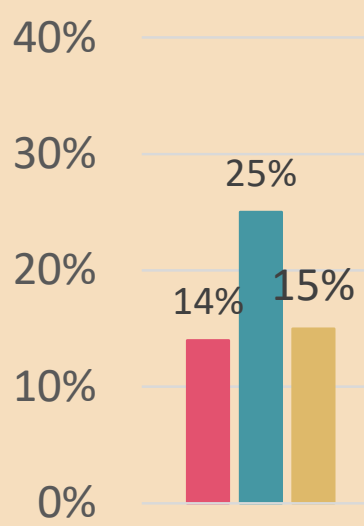

Pseudomonas

Table 3. Bacteria Etiology of Sepsis in Burn patients (September - November 2016)

\begin{tabular}{cccccc} 
Organism Etiology of Sepsis & $\begin{array}{c}\text { No. of Isolates* } \\
(\mathbf{n}=45)\end{array}$ & Wound Swab & Tissue & Sputum & Blood \\
\hline Pseudomonas aeruginosa & $15(33,3 \%)$ & 7 & 6 & 2 & 0 \\
Klebsiella pneumoniae & $13(28,9 \%)$ & 2 & 4 & 5 & 2 \\
Acinetobacter baumannii & $5(11,1 \%)$ & 2 & 1 & 2 & 0 \\
Enterobacter aerogenes & $3(6,7 \%)$ & 1 & 1 & 1 & 0 \\
Enterobacter cloacae & $3(6,7 \%)$ & 0 & 0 & 3 & 0 \\
$\quad \begin{array}{c}\text { Staphylococcus } \\
\text { saprophyticus }\end{array}$ & $2(4,4 \%)$ & 1 & 0 & 0 & 1 \\
$\quad \begin{array}{c}\text { Proteus mirabilis } \\
\text { Enterococcus faecalis }\end{array}$ & $2(4,4 \%)$ & 1 & 0 & 1 & 0 \\
Staphylococcus aureus & $1(2,2 \%)$ & 0 & 1 & 0 & 0 \\
$\quad 1(2,2 \%)$ & 0 & 1 & 0 & 0 \\
Total & 45 & 14 & 14 & 14 & 3
\end{tabular}

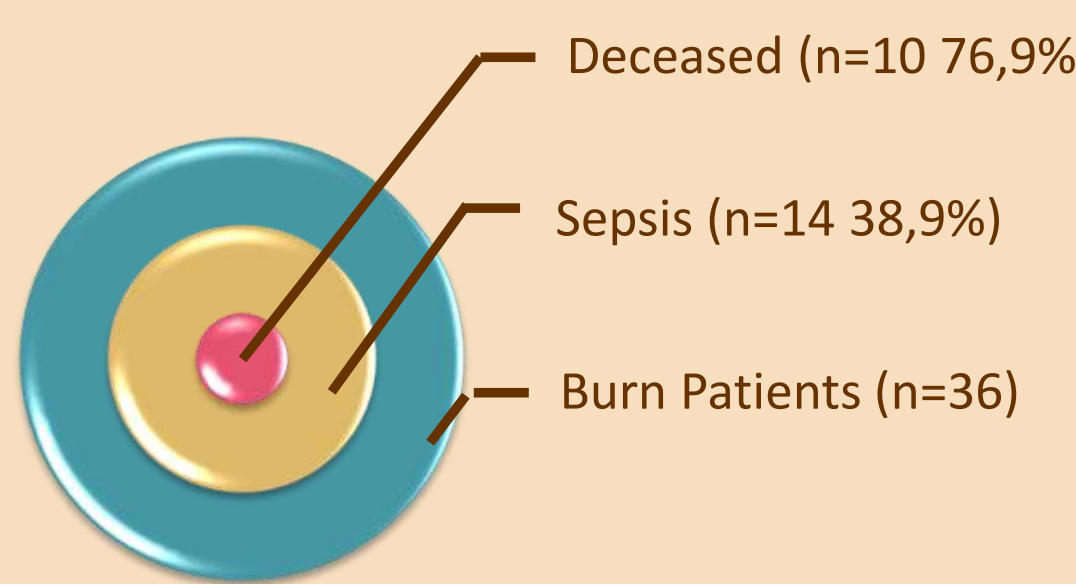

$20 \%$

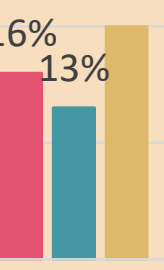

Others

$$
\text { (1) }
$$

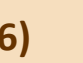

